\title{
Lithic raw material procurement in the Moravian Neolithic: the search for extra-regional networks
}

\author{
Martin Kuča', Antonín Přichystal'2, Zdeněk Schenk', Petr Škrdla3, and Milan Vokáč \\ 1 Department of Archaeology and Museology, Faculty of Arts, Masaryk University, Brno, CZ \\ makku@email.cz \\ 2 Department of Geology, Faculty of Science, Masaryk University, Brno, CZ \\ 3 Institute of Archaeology of ASCR in Brno, CZ
}

\begin{abstract}
The study of lithic raw material procurement can contribute to the study of ancient networks. Petrographic analysis combined with systematic mapping of raw material outcrops has been conducted in Moravia and adjacent territories by A. Prichystal over a period of more than three decades. Combined with well excavated (including wet-screening) and ${ }^{14} \mathrm{C}$ (radiometric) dated sites, allows us to study changes in the distribution networks of raw materials during the Mesolithic and Neolithic periods.
\end{abstract}

IZVLEČEK - Študij oskrbe s surovinami lahko prispeva $k$ razumevanju povezav v prazgodovini. A. Př́chystal je petrografske analize v povezavi s sistematičnim kartiranjem najdišč na Moravskem vodil več kot trideset let. Dobro izkopana in ${ }^{14} \mathrm{C}$ datirana najdišča omogočajo študij sprememb v mezolitskih in neolitskih surovinskih distribucijskih mrežah.

KEY WORDS - Moravia; Neolithic; raw materials; networks; ${ }^{14} \mathrm{C}$ chronology

\section{Introduction}

Since Neolithic cultures were first defined (Palliardi 1914) within the Middle Danube area, the main focus has been on pottery at the expense of other forms of material culture. The same trend may be documented during the entire $20^{\text {th }}$ century; however in its last decades several researchers changed their focus to the study of stone tools, both from the viewpoint of raw material utilized for their production and their typology (e.g. Príichystal, Mateiciucová). Since the year 2000, stone industries have attracted greater attention within the Moravian archaeological community (I. Mateiciucová, M. Vokáč, M. Kuča). This paper continues this trend by looking at the Moravian Neolithic mainly in terms of the stone industry - combined with ${ }^{14} \mathrm{C}$ chronology and the palaeoclimatic record - while attempting to summarize contemporary research questions and preliminary results. In recent studies, the role of pottery has declined. Although the authors acknowledge the important role of pottery analyses, this study aims to take an innovative approach to Neolithic development in the region.

\section{Methodology}

The analysis of raw material networks, particularly the distribution of specific varieties of raw material on the eastern Central European scale, has been the subject of several publications. While Lech (2003) studied the distribution of many types of siliceous rocks, Groneborn (2003a) focused on the distribution of several specific raw materials (Szentgál-type radiolarite, obsidian, Maas valley silicite, and Wittlingen chert). It is fruitful to study these raw material networks and compare them with hypothetical and radiocarbon record based models (Bocquet-Appel et 
al. 2009) of diffusion of the LBK and other Neolithic cultures across the European continent. Recently, Mateiciucová (2002) analyzed LBK raw materials from the Middle Danube area (Ph.D. thesis) and Kuča (2008) focused on the supply of Neolithic raw materials in a particular micro-region of the Brno Basin. One set of limitations regarding the methods used in Moravia is posed by the necessity of working with assemblages excavated and collected over a long period, by different people using different excavation methods, and often lacking in information concerning possible contamination

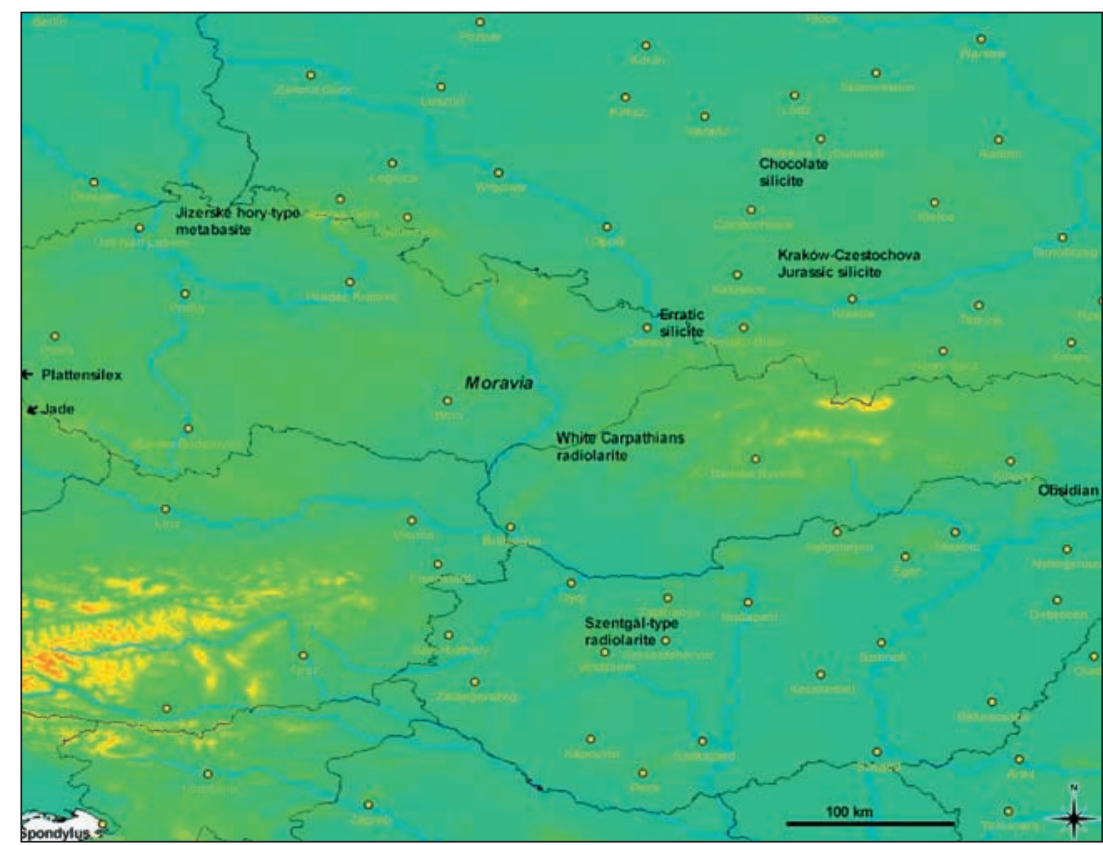

Fig. 1. Map showing raw materials imported into Moravia. by older or younger material (the majority of sites are poly-cultural). The lack of (or inconclusive) radiocarbon dating results is also a problem. Therefore, we have selected a set of reference-sites that we deem representative of each culture and cultural phase. The selected reference sites were excavated using modern field techniques (including wet-sieving and precisely fixing the provenance of all items) and dated using absolute dating methods. It will be necessary to excavate more such reference sites in Moravia in the near future.

An important innovation in lithic raw material studies has been the development of a non-destructive method of sourcing raw materials. Using this method, it has been possible to determine the source of many (hundreds to thousands) chipped artefacts. The method involves matching chipped silicic artefacts with raw materials from geological sources using a stereomicroscope with water as an immersion liquid (Prichystal 2002b). This research has resulted in the sourcing of thousands of Neolithic chipped artefacts which, in turn, has made it possible to reconstruct raw material distribution networks.

\section{The geographical and geological setting of Mo- ravia}

Moravia is a historical geographic unit (land) currently constituting the eastern half of the Czech Republic. From a geographical and geological point of view, Moravia lies on the boundary between the Western Carpathians in the east and the Bohemian
Massif in the west, and also on the Black Sea (Danube, southern Moravia), and the Baltic Sea watershed (Oder River, northern Moravia). The relief of Moravia consists of river valleys surrounded by highlands. The river valleys are connected by gates which form a system of passages - communication routes which connect eastern and western, northern and southern Europe (Svoboda et al. 1996).

During the last glaciation Moravia was a periglacial zone between the Alpine and Fenoscandinavian ice sheets and allowed movements (migrating animal herds, hunter-gatherers, raw materials) in both of the above-mentioned directions. After the LGM, people penetrated Moravia from both western and eastern refuges (cf. Semino et al. 2000), and the Morava River served as an arbitrary boundary between the western Magdalenian and eastern Epigravettian culture complexes. The north-south became part of the (later period) so-called amber route. These main communication routes are now being utilized for a network of motorways.

The relief, slope erosion and intensive agricultural use of the lowland fields in the past (ploughing has caused erosion and the disturbance of archaeological material located near the surface) has had a negative impact on the preservation of ancient sites.

\section{Local raw materials}

The area has highly diverse geology, with many geological units in a relatively small area. This is reflec- 
ted in the number of local and very often unusual raw materials (of different origin) suitable for both knapped and polished stone working.

\section{The knapped stone industry}

The most important locally available raw material is the Krumlovský Les-type chert. The main outcrops are in the Krumlovský Les Highland in southwestern Moravia (Oliva 1990; Oliva, Neruda, Prichystal 1999), where the nodules occur as pebbles with a characteristic black cortex (desert varnish) in Miocene gravel deposits. M. Oliva has documented the mining of this resource since the Mesolithic period (Oliva 2008). Isolated outcrops of this material, often of low-quality, are also known from another part of Moravia.

Other raw materials have been locally documented and include Olomučany-type chert, Stránská Skálatype chert, rock crystal, and Cretaceous spongolitic chert.

Isolated outcrops of Jurassic Olomučany-type chert are known only from the central part of the Moravian Karst (Prichystal 1999a).

The Jurassic Stránská Skála-type chert is present as nodules in organodetritic limestones at Stránská Skála hill on the eastern periphery of Brno (Prichystal 1994).

Primary sources of Cretaceous spongolitic chert occur in the general area of Boskovice Furrow (northwest of Brno) and secondary deposits can be found in the gravel terraces of south Moravian rivers (Prichystal 2002).

Rock crystal (respectively, smoky quartz, citrine and rose quartz) originates from pegmatites or quartz veins in the strongly metamorphosed crystalline rocks of the Bohemian-Moravian Highlands. This raw material is known to occur in colluvial deposits adjacent to the primary outcrops, as well as in (reworked) river gravels (Vokáč 2004); however, Alpine or Polish (Jeglowa) lithic sources may also have been used.

Various kinds of opal and chalcedony masses, which are the siliceous weathering products of various metamorphic rocks (especially of serpentinite), often called 'plasma, chalcedony, or opal', are known mainly from southwestern Moravia (Vokáč 2004); however there are less frequently utilized sources in other parts of Moravia and southern Bohemia (Prí chystal 2004). Because of the nature of this group of raw materials, sources are very difficult to identify unambiguously.

Apart from obsidian originating in the Carpathian region, the use of a very unique and unusual local raw material, moldavite (tektite, natural glass), has also been documented (e.g. Vokáč 2004).

\section{The polished stone industry}

The sources of hornblende diorite of the Rokle-type, first described by A. Prrichystal (1988), are in the Svratka River valley and its surroundings (northwestern outskirts of Brno). However, there is currently no direct evidence that it was mined (cf. Vokáč, Kuča, Príchystal 2005; Kuča, Vokáč 2008; Kuča, Kirchner, Kallabová in print).

The outcrops of diorite porphyry (porphyric microdiorite) are located to the west of Brno. Dykes of diorite porphyry intrude into both the granitoids and metabasites of the Brno Massif. They have a characteristically low magnetic susceptibility (Vokáč, Kuča, Přichystal 2005; Kuča, Vokáč 2008).

Outcrops of the chlorite-actinolite greenschist of the Želešice-type (see Prichystal 1999b; 2000a; 2000b; Kuča, Vokáč 2008) occur in the southeastern part of the Brno Massif. This raw material is characterized by a high magnetic susceptibility (1.5-55 x 10-3 SI units).

Both primary and secondary outcrops of amphibolites with banded structures are known in the Moldanubicum and Moravicum - geological units forming a strongly metamorphosed core of the Bohemian Massif in southeastern Moravia. Other possible sources are known to exist in the Hrubý Jeseník Mts. (northern Moravia) and the Malé Karpaty Mts. in western Slovakia.

Another important rock type for polished artefacts is eclogite, which is rock typically composed of garnet and pyroxene. There are local sources in the Moldanubicum; however, there are sources of eclogites in the Western Alps that were exploited in the Neolithic (e.g. D'Amico, Starnini 2000), and we cannot exclude the possibility that they were also imported from north-western Italy, as has been documented for jadeitites.

Culmian siltstones and silty shales are dark grey, fine-grained rocks from Lower Carboniferous formations in northern Moravia (Nízký Jeseník Mts.) and 
central Moravia (Drahany Highland, Maleník block). Greywackes used for polished hammer-axes occur in the same geological units (Janák, Prrichystal 2007).

Cenozoic volcanics (basalts, phonolites, andesites) are known from several outcrops within the Middle Danube area, e.g. in northern Moravia, Silesia, northern and central Hungary, southern Slovakia (Illášová 2001), as well as northern and western Bohemia. The location of their sources is still being investigated.

\section{Imported raw materials}

Imported raw materials are defined as those coming from sources over $30-40 \mathrm{~km}$ from the site (i.e. approximately a one-day walk). These distances are measured from the city of Brno, in southern Moravia.

\section{The knapped stone industry}

The radiolarites originating in the Balaton Lake area (Biró, Regenye 2007) were imported from the Bakony Mts. in Hungary. Local geologists distinguish several types of radiolarites (e.g. Szentgál, Sümeg, Harskút, Urkút-Eplény). This raw material was imported in the form of whole nodules or blocks. It is approx. $220 \mathrm{~km}$ as the crow flies from Brno to the sources of the Balaton radiolarites.

Obsidians were transported from Zemplínské Vrchy Upland, currently divided by the Slovak-Hungarian border. The only known obsidian source in Central Europe occurs in this area (Biró 1981; Illášová, Spišiak, Toronyiová, Turnovec 2004; Príchystal 2004). This is supported by all the currently available trace elements analyses of archeological finds.

The primary outcrops of the Kraków-Czestochova Jurassic silicite are located within the limestone area between Kraków and Czestochova in southern Poland. These outcrops are approx. $300 \mathrm{~km}$ from Brno.

The outcrops of so-called chocolate silicite are located in the northern foothills of the Holy Cross Mts. in Central Poland (Schild 1976). These outcrops are approx. $420 \mathrm{~km}$ from Brno.

The outcrops of a tabular banded Plattensilex (Arnhofen- and Baiersdorf type) are located in Bavaria, some $350 \mathrm{~km}$ from Brno.

The most important Bohemian raw materials are Tertiary quartzites from north-western Bohemia Skršín- type, Tušimice-type, Bečov-type (Neustupný 1966; Malkovský, Vencl 1995; Přichystal 2004).
These outcrops are located approx. $260 \mathrm{~km}$ from Brno.

We define erratic silicite as siliceous raw materials (silicites) collected from glacial and glacifluvial deposits in southern Poland and northern Moravia. The nearest such outcrops are approx. 110km from Brno. While in the northern Moravian sites, this raw material would be classified as local (i.e. it is not possible to separate the Polish from the Moravian sources), in central, western, eastern, and southern Moravia, it is an imported raw material.

Jurassic Carpathian or Alpine radiolarites were occasionally used in south-eastern Moravia. They were sourced in the White Carpathians on the MoravianSlovakian border, or at Mauern, Vienna. These outcrops are approx. $110 \mathrm{~km}$ from Brno.

\section{The polished stone industry}

A group of raw materials called metabasites of Jizerské hory-type comprise the most important raw material frequently utilized for polished artefact production in central Europe. It has low magnetic susceptibility values $\left(0.30-0.80 \times 10^{-3}\right.$ of SI units). The primary outcrops were discovered in northern Bohemia: Jistebsko (Šrein et al 2002) and Velké Hamry (Prichystal 2002a). The latest characterization of the whole mining area was carried out by Šída (2007). The metabasite of Jizerské Hory-type has had a complicated geological history, and from a petrological point of view, it can be described as a thermally metamorphosed greenschist. Some authors prefer to identify this material as hornblende-plagioclase hornfels. These outcrops are some $200 \mathrm{~km}$ from Brno.

The serpentinites originate from the Moldanubicum, and are characterized by high magnetic susceptibility values reaching dozens of SI units (Prichystal, Gunia 2001). Although this material is known from various sites in the Bohemian Massif, the most important source is probably in south-west Moravia (Weiss 1960). However, we cannot exclude the utilization of non-Moravian sources, such as those in southern Poland (Wojciechowski 1983). The distance of these outcrops from Brno is approx. $210 \mathrm{~km}$ (in Poland).

Gabbro is a rock used for the production of perforated tools, known sources of which occur in several areas, including the Orlické and Železné Mts. and in Lower Silesia (Ślęza Hill; Přichystal 1999a.222). The distance of these outcrops from Brno is around $200 \mathrm{~km}$ (in Poland). 
The commercial term 'jade' often includes one of two very different materials - nephrite or jadeitite. While the only nephrite source in Central Europe has been found near the village of Jordanów in Lower Silesia (Gunia 2000), for jadeitite there are sources in the western Alps (D'Amico, Starnini 2000). The distance of these outcrops from Brno is around $200 \mathrm{~km}$ (nephrite) and about $800 \mathrm{~km}$ (jadeitite).

Neolithic mining of white marble was described at Bílý Kámen hill near Sázava (Žebera 1939; Přichystal 2000a; 2000b). The distance of the outcrops from Brno is approx. $140 \mathrm{~km}$.

The shells of the mollusc Spondylus gaedoropus L., in the central European LBK of anticipated Mediterranean origin (Lenneis et al. 1995), were utilized for the production of personal adornments (Vencl 1959; Podborsky 2002). However, in Moravia the presence of this raw material has been documented not in the earliest LBK, but in later phases of LBK, most frequently as grave goods (e.g. in the Vedrovice burial ground, Podborsky et al. 2002). In Moravia, the importation of this raw material ceased towards the end of LBK, probably as a sequel to changes in interregional distribution networks.

On the other hand, there is evidence that the raw material distribution networks operated in both directions, i.e. Moravian raw materials were being exported. Due to their inexperience, lithic analysts and geologists in neighbouring countries often do not identify these materials as Moravian; for example, we were recently able to identify Moravian raw materials (diorites from the Brno area were found in eastern Slovakia, Krumlovský Les breccia in southern Poland, metabasite of the Jizerské hory-type in Austria and Hungary, etc.).

\section{The Late Paleolithic and Mesolithic background}

The number of excavated Late Paleolithic sites is very limited because of the lack of sunken features from this period, the absence of loess sedimentation, and intensive erosion during later periods (up to the present). The Late Paleolithic is represented by a local variety - Tišnovian (a local variant of Federmesser-Gruppen), and there are no absolute dates. Only one excavated site (Tišnov-Dřínová site) and several surface collections have been reported. While the local raw materials, often poor in quality, were used in the Czech-Moravian Highland, the erratic silicite and Kraków-Czestochova silicite were used in the Morava River valley, which is located on the main communication route and closer to the sources.

Sandy dunes were the preferred locations during the Mesolithic period. Such sites often poorly preserve organic material, and were intensively disturbed by rodents (cf. Škrdla, Poláček, Škojec 1999). Several Mesolithic sites have been excavated and several more surface sites have been reported. The absolute chronology of the Mesolithic period (by 'absolute chronology' we mean calibrated radiometric dates $-{ }^{14} \mathrm{C}$ or AMS) indicates an age range of 9 to 6 millennia BC (e.g. Valoch 1978; Svoboda 2003). Mesolithic people used local raw materials, often collected from river gravels; however, Oliva (2008) recently documented extraction pits dating back to the Mesolithic in the Krumlovský Les mining area.

\section{The Earliest Linear Band Pottery Culture (LBK) in Moravia}

The earliest LBK in Moravia has links to the western branch of this culture and is represented in Moravia by phase Ia, based on the relative chronology developed by Tichý (1962), and expanded by Čižmár (1998), Pavúk (2004), and Pavlù (2005). The dating of the occupation discovered recently in Spytihněv has shown that the already well-documented earliest presence of this phase in Moravia dates back to 5420-5220 calBC (cf. Schenk et al. 2008). This does not necessarily mean that this was the earliest presence of LBK in Moravia. Another absolute date (5580-5220 calBC, p95\%) is available from an earlier excavation at Žopy (Quitta 1967; Mateiciucová 2002). Another important site is at Brno-Ivanovice (Čižmár 1998), which yielded a date of 5570-5450 calBC (Stadler et al. 2000). Similar or identical absolute dates for the earliest LBK have been obtained for the broader region, including Lower Austria, Moravia, Bohemia, and southern Poland. Unfortunately, other examples of important Moravian LBK sites, often still lacking appropriate absolute dating, include Kladníky (Mateiciucová 2000), Vedrovice-Za Dvorem (Mateiciucová 2001), and Mohelnice (Tichý 1998, a Neolithic dendrochronology date exists for this site $-5450 \mathrm{BC}$ ).

The earliest Moravian LBK sites are generally located along the main rivers (e.g. Morava River) and follow the main natural geographic corridors connecting the Danube and Oder valleys. They are sometimes located on the margins of surrounding highlands, i.e. at strategic locations above the main river valleys (on hilltops). 
A significant change in raw material procurement in the form of much more extensive raw material networks is observed when compared to the preceding period of the last hunter-gatherers. The raw materials were imported from all directions, often from hundreds of kilometers away. The raw materials that were not imported, or not utilized to a great extent during the previous periods, began to assume greater importance (in the polished stone industry). The raw materials identified at the sites indicate more extensive networks than during the Mesolithic period, and similar or more extensive networks compared to the Upper Paleolithic period. The extra-regional contacts are represented by marine shells imported from the Mediterranean, Krakow-Czestochova Jurassic silicite, northwest Bohemian metabasites, Szentgál-type radiolarite from the Balaton Lake area, and obsidians from eastern Slovakia.

Although we currently have a number of the earliest LBK assemblages in Moravia, we prefer to use the recently excavated site at Spytihněv as a reference site (Schenk et al. 2008). This site was excavated to modern archaeological field-work standards (recording the provenance of all artefacts, wet-sieving all excavated sediments), and yielded a collection of characteristic pottery and a representative collection of knapped stone artefacts and several polished stone artefacts. Absolute dates have also been obtained. Another reference site is Žopy, where Pavelčik excavated a sunken feature in the 1950s which yielded a date and a collection of 71 stone artefacts (Groneborn 1997.169, Mateiciucová 2002).

The site at Spytihněv (49 $9^{\prime} 42.07^{\prime \prime} \mathrm{N}, 17^{\circ} 29^{\prime} 25.83^{\prime \prime E}$ - WGS-84) is located on a southerly ridge extending from Maková Hill. The site reaches an altitude of $322.1 \mathrm{~m}$ above sea level and rises to 135 meters above the Morava River. The site is in a strategic position that allows control of the lower Morava River valley. The collection of knapped stone from Spytihněv consists of 442 items, surprisingly dominated by erratic silicite (49\%), followed by Kraków-Czestochova Jurassic silicite (32\%). Contacts with the southeast Transdanubian region are indicated by the presence of Szentgál-type radiolarite (13\%). The polished stone artefacts from Spytihněv were made from Jizerské Hory-type metabasite and Želešice-type greenschist (Schenk et al. 2008). The raw material spectrum is surprisingly rich and indicates intensive contacts with northern Bohemia (metabasites), the Brno area (Želešice-type greenschist), the KrakówCzestochova area in Poland, the Balaton area (the Szentgál-type radiolarite) in Hungary, and eastern
Slovakia (obsidian). The contacts with southern and eastern territories were expected to be similar to the LBK core area; however, the intensive contacts with northern regions from the earliest phase of LBK are important for creating and testing the hypothesis of the spread of LBK further to the north.

The site of Žopy $\left(49^{\circ} 20^{\prime} 11.54^{\prime \prime} \mathrm{N} ; 1^{\circ} 35^{\prime} 44.25^{\prime \prime} \mathrm{E}-\right.$ WGS-84) is located in a brickyard, near the modern town of Holešov. The site is located in the Rusava River valley, a left-bank tributary of the Morava River, in the western foothills of the Hostýn Mountains, at an elevation of $250-255 \mathrm{~m}$ (the relative altitude above the Rusava River is $12-17 \mathrm{~m}$ ).

According to Mateiciucová (2002), Kraków-Czestochova Jurassic silicite prevails (63.1\%), supplemented by Szentgál-type radiolarite (10.5\%) and erratic silicite $(6.6 \%)$. Isolated artefacts were made from Úrkút/Eplény-type and Hárskút-type radiolarites, Krumlovský Les-type chert (variety I), and quartz. Details on polished stone raw materials are not available.

The third important site - Brno-Ivanovice - is located on the northern outskirts of the modern city of Brno (4915'38.001'N, 16³4'47.256"E, WGS-84), in the valley of the Ponávka River. The site reaches an altitude of $255-260 \mathrm{~m}$ and the relative altitude above the Ponávka is $10-20 \mathrm{~m}$. According to Mateiciucová (2001), the knapped stone industry was made on Olomučany-type chert (68\%), Moravian Jurassic chert (10\%), Krumlovský Les-type chert (variety II, 2\%), and isolated artefacts were made from Krumlovský Les-type chert (variety I), Kraków-Czestochova Jurassic silicite, Bakony radiolarite and quartz (Mateiciucová 2000.229). Details on polished stone raw materials are not available.

The Vedrovice-Za Dvorem site ( $49^{\circ} 0{ }^{\prime} 59.75^{\prime \prime} \mathrm{N}, 16^{\circ} 22$ ' 16.203 "E, WGS-84) is located on the south-eastern slopes of the Krumlovský Les upland and reaches an altitude of $250 \mathrm{~m}$. Based on a relative chronology, the earliest phase of LBK is present (Ia, information by Z. Čižmář). Mateiciucová (2001) described a collection of 255 artefacts from two sunken features (176 and 179). The collection is characterized by a prevalence of Krumlovský Les-type chert (variety I, 63.5\%), Olomučany-type chert (17.5\%), Krumlovský Les-type chert (variety II, 9\%). Only isolated artefacts were produced from Szentgál-type radiolarite, Kraków-Czestochova Jurassic silicite, and erratic silicite (Mateiciucová 2001.10). Relevant details on polished stone raw materials are not available. 
This brief introduction to the major earliest LBK lithic collections demonstrates the importance of imported raw materials and contrasts with the limited use of locally obtained raw materials. The radiolarites of Hungarian origin and obsidian from eastern Slovakia (or northeastern Hungary) indicate contacts to the south and east, i.e. to the LBK core area, and are traditionally accepted as documenting the spread of the earliest LBK from Transdanubia to Moravia and further north (cf. Groneborn 2003b; Mateiciucova 2002). These raw materials constitute around $10-15 \%$ of the raw material spectra; the majority of raw materials were imported from northern territories, i.e. the opposite direction to the currently suggested Neolithisation. The Kraków-Czestochova Jurassic silicite dominates such early LBK sites in northern Poland, which are dated to the same period (Boguszewo, Mateiciucová 2000; Malecka-Kukawka 1992). The similarity in raw material supply patterns over a large area documents the significance of the Kraków-Czestochova Jurassic silicite for the earliest LBK in Moravia and Poland and documents a rapid diffusion of the earliest LBK in the region. The prevalence of the Kraków-Czestochova Jurassic silicite over the Hungarian radiolarites at the earliest Moravian LBK sites enables us to posit an alternative hypothetical route for the Neolithisation of Moravia - from the northern Kraków area (there are several mountain passes through the Carpathians from Slovakia to the Kraków area). Obsidian had been imported into Poland since the Mesolithic period (Koztowski 1989.202). The presence of other imported raw materials such as erratic silicite and northern Bohemian metabasites support this 'provocative' hypothesis.

\section{The end of phase I and middle phase of LBK}

During the middle to late LBK (phases Ib to III are based on relative chronology), the occupation continues to penetrate deeply into the highlands and further from the main rivers; however, raw material procurement strategies are still similar to those of phase Ia.

The burial site at Vedrovice-Široká u Lesa, dated to phase Ib based on relative chronology, is one of the most important eastern Central European such sites (Podborsky et al. 2002). The grave-goods were produced primarily from Kraków-Czestochova Jurassic silicite (37.3\%), the local Krumlovský Les-type chert (25.4\%), Szentgál-type radiolarite (7.5\%), and included isolated artefacts made from Úrkút/Eplény-type radiolarite, reddish-brown radiolarite, erratic silicite and quartz (Mateiciucová 2002). Valuable grave goods are represented by a collection of artefacts made from Spondylus shells (Podborský et al. 2002).

In the middle phase of the LBK (phase II based on relative chronology, or the Musical Note Pottery phase of the LBK), density of occupation increased. The raw material networks were more extended and the quality of the raw material quality was a significant factor affecting choice. The Kraków-Czestochova Jurassic silicite dominate in the raw material spectra, supplemented in southern Moravia by locally available Krumlovský Les-type chert and Olomučanytype chert. Erratic silicite was almost ignored ( $c f$. Mateiciucová 2001). While during this phase the importation of the Szentgál-type of radiolarite was limited (Vedrovice-Za dvorem, Př́slavice-Kocourovec; Mateiciucova 1997) to the end of middle phase, and in connection with increasing influences from the east (Želiezovce from south-eastern Slovakia), this raw material again increased in importance (Mateiciucová 2001).

\section{The late phase of LBK}

Occupation density decreased during the late phase of LBK, and distribution networks changed (Mateiciucová 2001). While eastern (Želiezovce) influences disappeared, western influences (Š́rka) increased.

\section{Stroke Ornamented Pottery Culture (SPC)}

Moravia can be divided into a northern region, where the Stroked Pottery Culture is present, and a south-western, with Early MPWC and the episodic presence of Stroked Pottery Culture (SPC).

With the exception of several graves from TěšeticeKyjovice $-5915 \pm 30 \mathrm{BP}, 5920 \pm 30 \mathrm{BP}, 5960 \pm 30$ $\mathrm{BP}, 5970 \pm 30 \mathrm{BP}, 5915 \pm 30 \mathrm{BP}$, we currently have no radiocarbon dated SPC collections, and only preliminary results based on inadequately excavated collections are available. While northern and central Moravia are characterized by the predominance of erratic silicite (Olomouc-Slavonín, Určice), southern Moravia is characterized by local Krumlovský Lestype chert (Modřice, Křižanovice u Vyškova, Blučina) with imported erratic silicite present in small amounts. The local Olomučany-type chert, imported Bavarian plattensilex, north-west Bohemian quartzite, white marbles, Kraków-Czestochova Jurassic silicite, Szentgál-type radiolarite, and obsidian were documented only in small amounts (Oliva 1996; 
Kazdová et al. 1997; 1999; Čižmár̆, Oliva 2001). Due to the lack of well excavated and absolutely dated SPC sites, a detailed raw material analysis (compared to LBK or Lengyel culture analysis) is not available.

\section{Lengyel Culture (Moravian Painted Ware Cul- ture, MPWC) in Moravia and Mährisch-Österrei- chische Gruppe (MOG) in Austria}

The Lengyel Culture (in absolute chronology 48004000 calBC) is the most important upper Neolithic culture in the Middle Danube Region. In Moravia, two phases - I and II - were identified based on relative chronology (Kazdová, Koštuřik, Rakovský 1994; Čižmár et al. 2004; Pavúk 2007). MPWC sites have yielded the majority of the Neolithic radiocarbon dates from Moravia.

Currently, we have one of the earliest MPWC sites (phase Ia) reference sites in Moravia: Těšetice-Kyjovice - 'Sutny' (4853'55.019”N, 16 7'57.925”E, WGS 84) in the south-west (Kazdová 1984; Podborsky 1988; Kuča, Kazdová in print, etc.). A series of radiocarbon dates is available: $5450 \pm 90 \mathrm{BP}, 5625 \pm$ 40 BP, $5870 \pm 40$ BP (Podborsky 1975/76; Kazdová, Dočkalová in print). A collection of 1629 stone artefacts from selected sunken features was analyzed. The most commonly utilized material was the locally available Krumlovský Les-type chert (65\%), supplemented by local siliceous weathering products of serpentinites (6\%). Imported raw materials mainly include obsidian (14\%), and isolated artefacts were made from occasional silicite, Kraków-Czestochova Jurassic silicite, and radiolarite (Prichystal 1984). Polished stone items were produced from metabasite of the Jizerské hory-type, and there were significantly fewer artefacts of greenschist of the Želešicetype.

There are two reference sites from phase Ib for MPWC culture. Brrezník-Zadní Hon is located in the Czech-Moravian Highlands (49 $10^{\circ} 30.478^{\prime \prime} \mathrm{N}, 16^{\circ} 12^{\prime}$ 43.765" E, WGS 84). A single ${ }^{14} \mathrm{C}$ date is available for this site; $5780 \pm 40 \mathrm{BP}$ (Poz-22398; Kuča, Nývltová Fišáková, Škrdla, Vokáč in print). The dominant raw material is Krumlovský Les-type chert (95\%). Only isolated artefacts were made from imported chocolate silicite (1.4\%) and Kraków-Czestochova Jurassic silicite (1.0\%). The majority of raw materials used for polished artefacts were imported from the Brno area (greenschist of the Želešice-type, amphibolitic diorite of the Rokle-type, and diorite porphyry/porphyric microdiorite). Amphibolite and me- tabasite of the Jizerske hory-type were also occasionally used.

Šebkovice is the second important site of the Ib phase of MPWC, also located in the Czech-Moravian Highlands (49 6'35.42"N a 15 49'57.16"E, WGS 84). It is dated by ${ }^{14} \mathrm{C}$ to $5845 \pm 45 \mathrm{BP}$ (GrA-34102, $\mathrm{Ku}$ ča, Vokáč, Nývltová Fišáková in print). As in the previously described site, the Krumlovský Les-type chert prevails, supplemented by isolated artefacts made from local or regional origin (siliceous weathering products of serpentinites, opal, rock crystal, and chalcedony). More distant imports are comprised of isolated artefacts from chocolate silicite, obsidian, Kraków-Czestochova Jurassic silicite, erratic silicite, Bavarian plattensilex, and radiolarite. Polished tools were produced from greenschist of the Želešicetype, amphibolitic diorite of the Rokle-type, and diorite porphyry/porphyric microdiorite.

Three reference sites are available for phase Ic of MPWC. The first is Jezeřany-Maršovice-Na Kocourkách (49²'37.05”N, 16²4'59.873"E, WGS 84), 10cated directly on outcrops of Krumlovský Les-type cherts and dated to $5325 \pm 50 \mathrm{BP}$ (Bln-2067, Rakovsky 1985). The assemblage numbers 2097 knapped artefacts, with Krumlovský Les-type cherts predominant. Other raw materials are represented only by isolated items and include radiolarite, KrakówCzestochova Jurassic silicite, Bavarian plattensilex, erratic silicite, and chocolate silicite (Rakovsky 1985; Přichystal, Svoboda 1997; Oliva 2001). Polished artefacts have not been published yet.

The second site from this period (phase Ic, MPWC) is Brno-Bystrc $\left(49^{\circ} 13^{\prime} 12.516^{\prime \prime} \mathrm{N}, 16^{\circ} 31^{\prime} 11.014^{\prime \prime} \mathrm{E}\right.$, WGS 84), which yielded a date of $5570 \pm 60 \mathrm{BP}$ (Bln-2424, Rakovský 1985). The Krumlovský Lestype chert is again the most commonly used raw material, supplemented by Kraków-Czestochova Jurassic silicite, Olomučany-type chert, and Stránská Skálatype chert. Polished tools were produced from greenschist of the Želešice-type, amphibolitic diorite of the Rokle-type and diorite porphyry/porphyric microdiorite (Přrichystal 1988; Cižmárová, Rakovský 1988).

The third reference site from this period was excavated in Mokrá near Brno (49 ${ }^{\circ} 14^{\prime} 2.189$ 'N, $16^{\circ} 44^{\prime}$ 59.606 "E, WGS 84) on the southern margin of the Moravian Karst. Two dates are available; $5645 \pm 35$ BP (VERA 760, Šebela, Kuča 2004) and $5640 \pm 45$ BP (GrA-34088, Kuča 2008). Imported raw materials are present in significant proportions - erratic 
silicite and Kraków-Czestochova Jurassic silicite are followed by Krumlovský Les-type chert, Olomučanytype chert, Crecateous spongolitic chert, obsidian and chocolate silicite. Polished tools were produced from raw materials obtained in the Brno area (greenschist of the Želešice-type, amphibolitic diorite of the Rokle-type and diorite porphyry/porphyric microdiorite).

The only reference site for phase IIa of MPWC is Dluhonice $\left(49^{\circ} 27^{\prime} 47.311^{\prime \prime} \mathrm{N}, 17^{\circ} 25^{\prime} 8.528^{\prime \prime} \mathrm{E}\right.$, WGS 84) in the Moravian Gate, which yielded a ${ }^{14} \mathrm{C}$ date of 5675 $\pm 45 \mathrm{BP}$ (GrA-34089). Knapped artefacts were produced only from erratic silicite and Kraków-Czestochova Jurassic silicite. Polished tools were produced from greenschists of the Želešice-type.

A radiometrically dated site from phase IIb of MPWC is not currently available. Two dates are available from phase IIc of the MPWC from Jezeřany-Maršovice (Koštuřik et al. 1984; Oliva 2001); $5040 \pm 50$ BP (Bln-2068) and $5120 \pm 50 \mathrm{BP}$ (Bln-2142). The only identified raw material present is the local Krumlovský Les-type chert and chert breccia. Imported raw materials have not been identified. Polished tools were produced from greenschist of the Želešice-type, amphibolitic diorite of the Rokle-type and diorite porphyry/porphyric microdiorite, amphibolite, and greenschist of undetermined origin.

Except for the earliest phase (Ia) of the MPWC, southern Moravia was characterized by the exploitation of several local raw materials (see below), while the area far to the east and to the north-east of Brno is characterized by significant amounts of erratic silicite and Kraków-Czestochova Jurassic silicite ( $c f$. Mokrá; Šebela, Kuča 2004; Kuča 2008a). On the other hand, southwestern Moravia is a typical refuge area, with many local raw materials which were exploited at different rates (the Krumlovský Les-type cherts, siliceous geests, crystalline varieties of quartz, chalcedony, etc.; $c f$. Březník, Jezeřany-Maršovice, Šebkovice; Kuča, Nývltová Fišáková, Škrdla, Vokáč in print; Přichystal, Svoboda 1997; Oliva 2001; Kuča, Vokáčc, Nývltová Fišáková in print). The situation in the Brno area relates to south-western Moravia and is characterized by a predominance of Krumlovský Lestype chert; however, the area is rich in local raw materials suitable for polished stone production (amphibolitic diorite of the Rokle-type, diorite porphyry/ porphyric microdiorite, chlorite-actinolite greenschist of the Želešice-type; $c f$. Brno-Bystrc (Rakovský 1986; Čižmárová, Rakovský 1988). The lower Morava River valley and the Dyje-Svratka River val- leys are regions influenced both by the nearby outcrops of the Krumlovský Les-type cherts and by the imported Kraków-Czestochova Jurassic silicite and erratic silicite from the north. The upper Morava River valley, North Moravia or Moravian Gate, through the Vyškov Gate, served as corridors used for transporting raw material to southern and south-western Moravia ( $c f$. Dluhonice) during the MPWC.

Generally, the earliest (phase Ia) MPWC is characterized by a continuing tendency to use the local raw material, as is documented in the later phases of the LBK. During later phases (Ib-II) of the MPWC, the importation of rocks from the Brno area increases (greenschist of the Želešice-type, amphibolitic diorite of the Rokle-type, diorite porphyry/porphyric microdiorite). Polished stone items may have been valuable commodities traded for high-quality raw materials mainly from the north (the Kraków-Czestochova Jurassic silicite, chocolate silicite, erratic silicite?). During the later phases (Ib-II) of MPWC, imports are usually less numerous. Based on preliminary analyses, we can conclude that the Krumlovský Les-type silicite, erratic silicite and Kraków-Czestochova Jurassic silicite played a major role in the later phase (II) of the MPWC.

\section{Conclusion}

During the earliest LBK, raw materials were imported from all directions, often over distances of hundreds of kilometers. The extra-regional contacts are attested by the Krakow-Czestochova Jurassic silicite, north-west Bohemian metabasite, Szentgál-type radiolarite from the Balaton Lake area, and obsidian from eastern Slovakia (the obsidian demonstrates contacts with the region occupied by the eastern branch of the LBK). This raw material spectrum documents the extended raw materials networks which were connected to Moravia from all points of the compass, which is a contrast to the preceding Late Paleolithic and Mesolithic occupation, where the economy was based on the utilization of local raw materials. The extent to which the hunter-gatherer way of life survived until the Early Neolithic penetrated the main river valleys remains an open question. Taking into account the significant differences in the raw materials of the economy (and other aspects of social life) between the Mesolithic (Mikulčice, Smolín) and the earliest LBK (reference sites), contact between the two cultural complexes appears to have been very limited. However, in order to test interaction hypotheses, more radiometric dates are needed. 
During the later phases of the LBK, the imported raw material (Krakow-Czestochova Jurassic silicite, northwest Bohemian metabasite, and Szentgál-type radiolarite) continued to be significant; however, the amount of local raw materials increase, and this is clearly visible, especially in southern and south-western Moravia (an area rich in quality local raw material sources). The valuable grave goods and the most distant contacts are represented by a collection of artefacts made from Spondylus shells.

The western influences (from Germany) led to a significant difference in raw material spectra during the SPC. This is demonstrated by the presence of western raw materials not previously imported to Moravia (Bavarian plattensilex, north-west Bohemian quartzite, and white marble). The Kraków-Czestochova Jurassic silicite, Szentgál-type radiolarite, and obsidian imports continue to be significant, but they are present in smaller quantities. The use of local raw materials is similar to the later phases of the LBK and continues in similar proportions until the end of the Neolithic. The main extra-regional contacts are indicated by the presence of Bavarian plattensilex, Kraków-Czestochova Jurassic silicite, Szentgál-type radiolarite, and obsidian. The area of the obsidian outcrops was occupied by the Bükk culture people, and the Lake Balaton area was occupied by bearers of the earliest Lengyel Culture.

The earliest phase of MPWC (Ia) is characterized by similarities with the later phases of the LBK, both in artefact typology and raw materials (e.g. north-west Bohemian metabasites). A significant change begins with phase $\mathrm{Ib}$, which is characterized by increasing regionalization and utilization of local raw materials (especially for polished stone). While the KrakówCzestochova Jurassic silicite maintains its importance, obsidian began to play a more important role than before. Chocolate silicite from central Poland occurs for the first time. The extensive raw material networks present highly exotic and high-quality raw materials such as nephrite and jadeitite, documented in the early phase of MPWC (Vokáč 2008). Beginning from phase Ic, and during phase II of MPWC, raw material supply is characterized by the prevailing

\begin{tabular}{|c|c|c|c|c|c|c|}
\hline Lab. Number & Site & $\begin{array}{l}\text { Culture/ } \\
\text { Phase }\end{array}$ & $\begin{array}{l}{ }^{14} \mathrm{C}-\mathrm{Age} \\
{[\mathrm{BP} \pm \mathrm{STD}]}\end{array}$ & $\begin{array}{l}\text { CalAge p(95\%) } \\
\text { calBC }\end{array}$ & $\begin{array}{l}\text { CalAge } \mathrm{p}(68 \%) \\
\text { calBC }\end{array} \mid$ & Reference \\
\hline$\overline{B l n}-57$ & Żopy & LBK Ia & $6430 \pm 100$ & $5580-5220$ & \begin{tabular}{|l|l}
$5400 \pm 90$ \\
\end{tabular} & Felber, Ruttkay 1983 \\
\hline Poz-21786 & Spytihněv & LBK la & $6340 \pm 40$ & $5420-5220$ & $5320 \pm 50$ & $\begin{array}{l}\text { Schenk, Kuča, Škrdla, } \\
\text { Roszková } 2008\end{array}$ \\
\hline 1272 & Těšetice & LBK II & $6150 \pm 35$ & $5260-4980$ & $5120 \pm 70$ & Kazdová, Dočkalová in print \\
\hline$\overline{1275}$ & Těšetice & LBK II & $6210 \pm 35$ & $5300-5020$ & $5160 \pm 70$ & Kazdová, Dočkalová in print \\
\hline 1276 & Těšetice & LBK II & $6210 \pm 35$ & $5300-5020$ & $5160 \pm 70$ & Kazdová, Dočkalová in print \\
\hline VERA-4591 & Těšetice & LBK II & $6225 \pm 35$ & $5350-5030$ & $5190 \pm 80$ & Kazdová, Dočkalová in print \\
\hline VERA-4590 & Těšetice & LBK II & $6210 \pm 35$ & $5300-5020$ & $5160 \pm 70$ & Kazdová, Dočkalová in print \\
\hline Poz-22715 & Těšetice & LBK II & $6200 \pm 30$ & $5270-5030$ & $5150 \pm 60$ & Kazdová, Dočkalová in print \\
\hline Těšetice & Těšetice & MPWC Ia & $5450 \pm 90$ & $4490-4050$ & $4270 \pm 110$ & Podborský 1975/76 \\
\hline Těšetice & Těšetice & MPWC Ia & $5800 \pm 60$ & $4790-4510$ & $4650 \pm 70$ & Podborský 1975/76 \\
\hline GrA-34102 & Šebkovice & MPWC Ib & $5845 \pm 45$ & $4850-4570$ & $4710 \pm 70$ & $\begin{array}{l}\text { Kuča, Vokáć, Nývltová Fišáková } \\
2009\end{array}$ \\
\hline Poz-22398 & Březník & MPWC Ib & $5780 \pm 40$ & $4750-4510$ & $4630 \pm 60$ & $\begin{array}{l}\text { Kuča, Nývltová Fišáková, } \\
\text { Škrdla, Vokáč in print }\end{array}$ \\
\hline Poz-22525 & Pavlov & MPWC IC & $5780 \pm 35$ & $4730-4530$ & $4630 \pm 50$ & Kuča in preparation \\
\hline GrA-34088 & Mokrá & MPWC IC & $5640 \pm 45$ & $4590-4350$ & $4470 \pm 60$ & Кис̌a $2008 a$ \\
\hline VERA-76o & Mokrá-lom & MPWC IC & $5645 \pm 35$ & $4560-4400$ & $4480 \pm 40$ & Šebela, Kuča 2004 \\
\hline Bln-2067 & $\begin{array}{l}\text { Jezeřany- } \\
\text { Maršovice }\end{array}$ & MPWC IC & $5325 \pm 50$ & $4320-4000$ & $4160 \pm 80$ & Rakovský 1985 \\
\hline GrA-34089 & Dluhonice & MPWC lia & $5675 \pm 45$ & $4620-4420$ & $4520 \pm 50$ & Kuča in preparation \\
\hline Bln-2068 & $\begin{array}{l}\text { Jezeřany- } \\
\text { Maršovice }\end{array}$ & MPWC lic & $5040 \pm 50$ & $4010-3690$ & $3850 \pm 80$ & $\begin{array}{l}\text { Koštuřik, Rakovský, Peške, } \\
\text { Přichystal, Salaš, Svoboda } 1984\end{array}$ \\
\hline Bln-2142 & $\begin{array}{l}\text { Jezeřany- } \\
\text { Maršovice }\end{array}$ & MPWC lic & $5120 \pm 50$ & $4040-3760$ & $3900 \pm 70$ & $\begin{array}{l}\text { Koštuřik, Rakovský, Peške, } \\
\text { Přichystal, Salaš, Svoboda } 1984\end{array}$ \\
\hline$B \ln -2424$ & Brno-Bystrc & MPWC IC & $5570 \pm 60$ & $4520-4320$ & $4420 \pm 50$ & Rakovský 1985 \\
\hline Vera-2596 & $\begin{array}{l}\text { Brno-Ivano- } \\
\text { vice (Globus) }\end{array}$ & LBK I & $6545 \pm 40$ & $5570-5450$ & $5510 \pm 30$ & Stadler et al. 2000 \\
\hline
\end{tabular}

Tab. 1. List of available radiometric dates from Moravia, calibrated using CaPal, ver. 07. 
use of local raw materials. Extra-regional contacts are limited and can be demonstrated only along the main communication corridors which played a more important role (imports of obsidian or Kraków-Czestochova Jurassic silicite). However, 'prestigious' imports of high quality raw materials from more distant areas (chocolate silicite, jadeitite, nephrite) are also occasionally present, but the tools made from these materials may have had a symbolic or prestigious function and consequently may not reflect regular raw material networks.

We can conclude that Moravia, rich in local raw materials derived from its complicated geological struc- ture, was an important communication corridor (and also a node at the junction of several corridors) not only during the Neolithic, and this is reflected in the diverse and extensive raw material networks.

\section{ACKNOWLEDGEMENTS}

Our thanks go to Eliška Kazdová for providing unpublished radiocarbon dates and to Miriam Nyvltová Fišáková for her kind assistance with calibrating radiometric ages. Our work was supported by GAAVČR project No. A80001080 VaGAČR project No. 404/09/ 4020.

\section{REFERENCES}

BIRÓ T. K. 1981. A Kárpát-medencei obszidiánok viszegálata. Archaelógiai Értsitö 108: 196-205.

BIRÓ K., REGENYE J. 2007. Exploitation and workshop sites in the Bakony mts.: Study of the lithic material. In J. K. Kozłowski, P. Raczky (eds.), The Lengyel, Polgár and related cultures in the Middle/Late Neolithic in Central Europe. Kraków: 261-268.

BOCQUET-APPEL J.P., NAJI S., VANDER LINDEN M., KOZŁOWSKI J. K. 2009. Detection of diffusion and contact zones of early farming in Europe from the space-time distribution of ${ }^{14} \mathrm{C}$ dates. Journal of Archaeological Science 36: $807-820$.

ČIŽMÁŘ Z. 1998. Nástin relativní chronologie lineární keramiky na Moravě. Acta Musei Moraviae Sci. soc. 83 (1-2): 105-139.

ČIŽMÁŘ Z., OLIVA M. 2000. K ekonomii surovin štípané industrie lidu s vypíchanou keramikou na Moravě. In Otázky neolitu a eneolitu našich zemí. 18. pracovní setkání v Mostkovicích 14.-17. 9. 1999. Pravěk Supplementum 6: 97-130.

ČIŽMÁŘ Z., PAVÚK J., PROCHÁZKOVÁ P., ŠMÍD M. 2004. K problému definování finálního stádia lengyelské kultury. In B. Hänsel, E. Studeníková (eds.), Gedenkschrift für Viera Němejcová-Pavúková. Internationale Archäologie. Studia honoraria 21. Rahden/Wetf: 207-232,

ČIŽMÁŘOVÁ J., RAKOVSKÝ I. 1988. Sídliště lidu s moravskou malovanou keramikou v Brně-Bystrci. Archeologické rozhledy 40: 481-523.

D'AMICO C., STARNINI E. 2000. Eclogites, jades and other HP metaophiolites of the Neolithic polished stone tools from Northern Italy. Krystalinikum 26: 9-20.
FELBER H., RUTTKAY E. 1983. Absolutchronologie des Neolithikums in Österreich. Mitteilungen der Anthropologischen Gesellschaft in Wien 113: 73-78.

GRONEBORN D. 1997. Silexartefakte der ältestbandkeramischen Kultur. Mit einem Beitrag von Jean-Paul Caspar. Universitätsforschungen zur prähistorischen Archäologie, Band 37. Verlag Dr. Rudolf Habelt. Bonn.

2003a. Lithic raw material networks and the Neolithization of Central Europe. In L. Burnez-Lanotte (ed.), Production and Management of Lithic Materials in the European Linearbandkeramik/Gestion des matériaux lithiques dans le Rubané européen. Actes du XIVème Congrès UISPP, Université de Liège, Belgique, 2-8 septembre 2001. BAR International Series 1200. Oxford 2003: 45-50.

2003b. Migration, acculturation and culture change in western temperate Eurasia, 6500-5000 cal BC. In M. Budja (ed.), 10th Neolithic Studies. Documenta Praehistorica 30: 79-91.

GUNIA P. 2000. Nephrit from South-Western Poland as potential raw material of the European Neolithic artefacts. Krystalinikum 26: 167-171.

ILLÁŠOVÁ L. 2001. Alkali basalts: raw material of the Neolithic and Aeneolithic implements (Slovakia). Slovak geological magazine 7(4): 365-368.

ILLÁŠOVÁ L., SPIŠIAK J., TORONYIOVÁ M., TURNOVEC I. 2004. Obsidián: prírodná zaujímavost' z Viničiek pri Trebišove. Nitra.

JANÁK V., PŘICHYSTAL A. 2007. Ateliér kultury nálevkovitých pohárů na výrobu broušené industrie z kulmských hornin v Holasovicích, okr. Opava. Archeologické studie Univerzity Hradec Králové 1: 177-188. 
KAZDOVÁ E. 1984. Těšetice-Kyjovice 1. Starší stupeň kultury s moravskou malovanou keramikou. Spisy FF UJEP. Brno.

KAZDOVÁ E., KOŠTUŘÍK P., RAKOVSKÝ I. 1994. Der gegenwärtige Forschungsstand der Kultur mit mährischer bemalte Keramik. In International Symposium über die Lengyel-Kultur 1888-1988. Brno-Lódz: 131-155.

KAZDOVÁ E., PEŠKA J., MATEICIUCOVÁ I. 1999. OlomoucSlavonín (I). Sídliště kultury s vypíchanou keramikou. Archaeologiae Regionalis Fontes 2. Archeologicke centrum. Olomouc.

KAZDOVÁ E., ŠEBELA L., PŘICHYSTAL A. 1997. Besiedlung des Gebietes Blučina (Kr. Brno-venkov) durch Träger der Stichbandkeramik. Přehled výzkumů 1993-1994: 45-75.

KOŠTUŘÍK P., RAKOVSKÝ I., PEŠKE L., PŘICHYSTAL A., SALAŠ M., SVOBODA J. 1984. Sídliště mladšîho stupně kultury s moravskou malovanou keramikou $\mathrm{v}$ Jezeřanech-Maršovicích. Archeologické rozhledy 36: 378-410.

KOZŁOWSKI S. K. 1989. Mesolithic in Poland. A new Approach. Wydownictva Universytetu Warszawskiego. Warszawa.

KUČA M. 2008a. Sídliště fáze Ic kultury s moravskou malovanou keramikou v Mokré u Brna, okr. Brno-venkov. In Klápště J., Měřínský Z. (eds.), Dissertationes Archaeologicae Brunenses/Pragensesque. Supplemetum I. Moravskoslezská škola doktorských studií. Seminár 1. Brno: 36-41.

2008b. Exploitation of raw materials suitable for chipped stone industry manufacture in the Moravian Painted Ware Culture in the Brno region. Prehled výzkumi 49: 93-107.

KUČA M., KAZDOVÁ E. in press. Těšetice-Kyjovice 7. Osídlení s moravskou malovanou keramikou v prostoru mezi přikopem a vnější palisádou rondelu. Brno.

KUČA M., KIRCHNER K., KALLABOVÁ E. 2009. Exploatace surovin vhodných $\mathrm{k}$ výrobě broušené kamenné industrie ve spojitosti s antropogenním ovlivněním reliéfu $\mathrm{v}$ údolí střední Svratky (Morava, Česká republika). Ve službách archeologie. In service to archaeology 2009. Nitra: 38- 42.

KUČA M., NÝVLTOVÁ FIŠÁKOVÁ M., ŠKRDLA P., VOKÁČ M. in press. Lokalita staršîho stupně kultury s MMK v Březníku na Českomoravské vrchovině. In E. Kazdová (ed.), Otázky neolitu a eneolitu našich zemí. Brno.

KUČA M., VOKÁČ M. 2008. Exploitation of rocks for polished stone industry from the Brno Massif, South Moravia (Czech Republic). In A. Přichystal, L. Krmíček, M. Halavínová (eds.), Petroarchaeology in the Czech republic and Poland at the beginning of the 21st century. Ustav geolo- gických věd, Moravské zemské muzeum. Brno-Wroclaw: 95-109.

KUČA M., VOKÁČ M., NÝVLTOVÁ FIŠÁKOVÁ M. 2009. Sídliště kultury s moravskou malovanou keramikou v Šebkovicích a jeho přínos $\mathrm{k}$ absolutnímu datování mladého neolitu na Českomoravské vrchovině. Acta musei Moraviae 94: 65-88.

LECH J. 2003. Mining and siliceous rocks supply to the danubian early farming communities (LBK) in eastern central Europe: a second approach. In L. Burnez-Lanotte (ed.), Production and Management of Lithic Materials in the European Linearbandkeramik/Gestion des matériaux lithiques dans le Rubané européen. Actes du XIVème Congrès UISPP, Université de Liège, Belgique, 2-8 septembre 2001. BAR International Series 1200.0xford: 19-30.

LENNEIS E., NEUGEBAUER-MARESCH C., RUTTKAY E. 1995. Jungsteinzeit im Osten Österreichs. Forschungsberichte zur Ur- $u$. Frühgeschichte 17: 108-209.

MAŁECKA-KUKAWKA J. 1992. Krzemieniarstwo społeczności wczesnorolniczych ziemi chetmińskiej (2 połowa VI - IV tysiaclecie p.n.e). Wydawnictwo Uniwersytetu Mikołaja Kopernika. Torun.

MALKOVSKÝ M., VENCL S. 1995. Quartzites of North-West Bohemia as Stone Age raw materials: environs of the towns of Most and Kadaň, Czech Republic. Památky archeologické 86: 5-37.

MATEICIUCOVÁ I. 1997. Rozbor štípané industrie. In Horáková J. et al. (eds.), Osada lidu kultury s LnK v Př́áslavicích - Koucourovci. Archeologiae Regionalis Fontes 1: 99-105.

2000. Časně neolitická štípaná industrie z osady Kladníky a Ivanovice na Moravě. Památky archeologické Supplementum 13: 218-237.

2001. Mechanismy distribuce štípané industrie v mezolitu a neolitu aneb význam importovaných kamenných surovin. In Metlička (ed.), Otázky neolitu a eneolitu našich zemí. Plzeň: 7-18.

2002. Počátky neolitu ve střední Evropě ve světle zkoumání štípané kamenné industrie raně zemědělských společností (LnK) na Moravě a volním Rakousku: 5700-4900 přn.l. Unpublished PhD dissertation. Masaryk University. Brno.

NEUSTUPNÝ E. 1966. L'exploitation néolithique et énéolithique du quarzite à Tušimice (Bohême). In J. Filip (ed.), Investigations archéologiques en Tchécoslovaquie état actuel des recherches et leur organisation. Actes du $7 \mathrm{e}$ congrès de l'Union internationale des sciences préhistoriques et protohistoriques, Prague, 1966. Académie tchécoslovaque des sciences Prague: 65-66. 
OLIVA M. 1990. Štípaná industrie kultury s moravskou malovanou keramikou v jihozápadní části Moravy. Acta musei Moraviae sci. soc. 75: 17-37.

1996. Štípaná industrie kultury s vypíchanou keramikou v Těšeticích-Kyjovicích (K otázce výběru surovin v neolitu jižní Moravy). Acta musei Moraviae sci. soc. 81: 101-109.

1998. Pravěká těžba silicitů ve střední Evropě. Pravěk Ň̌ 8: 3-83.

2001. Sídliště lidu s moravskou malovanou keramikou v okolí Krumlovského lesa a jejich štípané industrie. Pravěk supplementum 8: 197-231.

2008. Moravský Krumlov (okr. Znojmo). Přehled výzkumi̊ 49: 239.

OLIVA M., NERUDA P., PŘICHYSTAL A. 1999. Paradoxy těžby a distribuce rohovce z Krumlovského lesa. Památky archeologické 90: 229-318.

PALLIARDI J. 1914. Die relative Chronologie der jüngeren Steinzeit in Mähren. Wiener Prähistorische Zeitschrift I: $256-277$.

PAVLŮ I. 2005. Neolitizace střední Evropy. Archeologické rozhledy 55: 293-302.

PAVÚK J. 2004. Stará lineárna keramika na Slovensku a neolitizácia strednej Európy. In M. Lutovský (ed.), Otázky neolitu a eneolitu našich zemí. Sborník referátů z 22. pracovního setkání badatelů zaměřených na výzkum neolitu a eneolitu. Český Brod-Kounice 23. - 26. 9. 2003. Praha: 11-28.

2007. Zur Frage der Entstehung und Verbreitung der Lengyel-Kultur. In J. K. Kozłowski and P. Raczky (eds.), The Lengyel, Polgár and related cultures in the Middle/Late Neolithic in Central Europe. Polish Academy of Arts and Sciences. Kraków: 11-28.

PODBORSKÝ V. 1975/76. Hlavní výsledky v Těšeticích-Kyjovicích za léta 1964 až 1974. Sborník prací Filozofické fakulty brněnské univerzity, řada E 20-21: 175-184.

1988. Těšetice-Kyjovice 4. Rondel osady lidu s moravskou malovanou keramikou. Brno.

2002. Spondylový šperk v hrobech lidu s lineární keramikou ve Vedrovicích. Archeologické rozhledy 54: 223-240

PODBORSKÝ V., ONDRUŠ V., ČIŽMÁ̌̌ Z., SALAŠ M., PŘICHYSTAL A., MATEICIUCOVÁ I., HLADILOVÁ Š., NEUSTUPNÝ E., RAJCHL R. 2002. Dvě pohřebiště neolitického lidu s lineární keramikou ve Vedrovicích na Moravě. Filozofická fakulta Masarykovy university, Brno.
Pर̌ICHYSTAL A. 1988. Petrografické studium štípané a broušené industrie $\mathrm{z}$ lokality s moravskou malovanou keramikou v Brně-Bystrci. Archeologické rozhledy 40: 508-512.

1999a. Lithic raw materials used by the people with Moravian Painted Ware (Lengyel cultural complex) in Moravia (Czech Republic). Lengyel 99 and IGCP-442 conference (abstracts). Veszprém: 46-50.

1999b. The petrographic Investigation of Stone Artefacts of the Corded Ware Culture in Moravia and the Adjacent Part of Silesia. In L. Šebela (ed.), The Corded Ware Culture in Moravia and Adjacent Part of Silesia. Fontes Archaeologiae Moravicae 23: 213-223.

2000a. Stone raw materials of the Neolithic-Aeneolithic polished artefacts in the Czech republic: The present state ok knowledge. Krystalinikum 26: 119-136.

2000b. Neolitické-eneolitické broušené artefakty v České republice $\mathrm{z}$ hlediska kamenných surovin. Pravěk NR 10: 41-70.

2002a. Petrografický výzkum broušené a ostatní kamenné industrie z vedrovických pohřebišt'. In V. Podborský (ed.), Dvě pohřebiště neolitického lidu s lineární keramikou ve Vedrovicích na Moravě. Masarykova univerzita. Brno: 211-215.

2002b. Zdroje kamenných surovin. In J. Svoboda (ed.), Paleolit Moravy a Slezska. Dolnověstonické studie 8: 67-76.

2004. Česká naleziště surovin na výrobu kamenných štípaných artefaktů v pravěku. Památky archeologické 95: 5-30.

PŘICHYSTAL A., SVOBODA. J. 1997. Výroba štípané industrie na sídlišti kultury s moravskou malovanou keramikou v Jezeřanech-Maršovicích. Přehled výzkumů 199394: 15-25.

PŘICHYSTAL A., GUNIA P. 2001. Magnetic properties of Lower Silesia serpentinites and some serpentinite artefacts from SW Poland and Moravia. Slovak Geological Magazine 7(4): 421-422.

PŘICHYSTAL A., TRNKA G. 2001. Raw materials of polished artefacts from two Lengyel sites in Lower Austria. Slovak Geological Magazine 7(4): 337-339.

QUITTA H. 1967. The C 14 Chronology of the Central and SE European Neolithic. Antiquity 51: 263-270.

RAKOVSKÝ I. 1985. Morava na prahu eneolitu. Unpublished PhD dissertation. Brno.

1986. Die neige der älteren Stufe der Kultur mit mährischer bemalter Keramik im Lichte der Funde aus Jeze- 
řany-Maršovice und Brno-Bystrc. In Internationales Symposium über die Lengyel-Kultur. Nové Vozokany 5.-9. 11. 1984. Nitra-Wien: 243-250.

REIMER P. J., BAILLIE M. G. L., BARD E., BAYLISS A., BECK J. W., BERTRAND C. J. H., BLACKWELL P. G., BUCK C. E., BURR G. S., CUTLER K. B., DAMON P. E., EDWARDS R. L., FAIRBANKS R. G., FRIEDRICH M., GUILDERSON T. P., HOGG A. G., HUGHEN K. A., KROMER B., MCCORMAC G., MANNING S., RAMSEY C. B., REIMER R. W., REMMELE S., SOUTHON J. R., STUIVER M., TALAMO S., TAYLOR F. W., VAN DER PLICHT J., and WEYHENMEYER C. E. 2004. IntCal04 terrestrial radiocarbon age calibration, 0-26 cal kyr BP. Radiocarbon 46: 1029-1058.

SCHENK Z., KUČA M., ŠKRDLA P., ROSZKOVÁ A. 2008. Spytihněv (okr. Zlín). Přehled výzkumů 49: 287-292.

SCHILD R. 1976. Silicite Minning and Trade in Polish Prehistory as Seen from the Perspective of the Chocolate Silicite of Central Poland. A Second approach. Acta Archaeologica Carpathica 16: 147-177.

SEMINO 0., PASSARINO G., OEFNER P. J., LIN A. A., ARBUZOVA S., BECKMAN L. E., DE BENEDICTIS G., FRANCALACCI P., KOUVATSI A., LIMBORSKA S. 2000. The genetic legacy of Paleolithic Homo sapiens sapiens in extant Europeans: a Y chromosome perspective. Science 290: 11551159 .

STADLER P., DRAXLER S., FRIESINGER H., KUTSCHERA W., PRILLER A., ROM W., STEIER P., WILD E. M. 2000. Status of the Austrian Science Fund Project P-12253-PHY: Absolute Chronology for Early Civilisations in Austria and Central Europe using ${ }^{14} \mathrm{C}$ Dating with Accelerator Mass Spectrometry. Projektbericht an den FWF als Manuskript.

SVOBODA J., LOŽEK V., VLČEK E. 1996. Hunters Between East and West: The Paleolithic of Moravia. Plenum Press. New York \& London.

SVOBODA J. 2003. Mezolitické osídlení severních Čech. In J. Svoboda (ed.), Mezolit severnich Čech. Dolnověstonické studie 9: 77-96.

ŠEBELA L., KUČA M. 2004. Objekt 3/1996 z Mokré (okr. Brno-venkov) a jeho přínos $\mathrm{k}$ datování závěru I. stupně kultury s MMK. In M. Lutovský (ed.), Otázky neolitu a eneolitu našich zemí. Sborník referátů z 22. pracovního setkání badatelů zaměřených na výzkum neolitu a eneolitu. Český Brod-Kounice 23.-26. 9. 2003. Praha: 271-285.

ŠÍDA P. 2007. Využívání kamenné suroviny v mladši a pozdni době kamenné. Dílenské areály v oblasti horní ho Pojizeř́. Dissertationes Archaeologicae Brunenses/Pragensesque 1. Praha-Brno.
ŠKRDLA P., MATEICIUCOVÁ I., PŘICHYSTAL A. 1997. Mesolithikum (gespaltene Steinindustrie). In L. Poláček (ed.), Studien zum Burgvall von Mikulčice, Band 2. Brno: 4591.

ŠKRDLA P., POLÁČEK L., ŠKOJEC J. 1999. Mikulčice (okr. Hodonín). Přehled výzkumů 39: 249-258.

ŠREIN V., ŠREINOVÁ B., ŠŤASTNÝ M., ŠÍDA P., PROSTŘEDNÍK J. 2002. Neolitický těžební areál na katastru obce Jistebsko. Archeologie ve středních Čechách 6(1): 91-99.

TICHÝ R. 1962. Osídlení s volutovou keramikou na Moravě. Památky archeologické 53: 245-305.

1998. Neolithic wells from Mohelnice. Materiallien zur Bodendenkmalpflege im Rheinland 10: 45-50.

1998. The context of the Early-LBK well at Mohelnice. In H. Koschik (ed.), Brunnen der Junsteinzeit. Internationales Symposium in Erkelenz 27 bis 29. October 1997. Materialen Bodendenkmalpflege Rheinland 11: 45-50.

VALOCH K. 1978. Die endpaläolitische Siedlung in Smolín. Studie Archeologického ústavu ČSAV v Brně 6. Praha.

VENCL S. 1959. Spondylové šperky v podunajském neolitu. Archeologické rozhledy 11: 699-741.

VOKÁČ M. 2004. Suroviny štípané kamenné industrie v pravěku jihozápadní Moravy. Acta musei Moraviae 89: 167-206.

2008. Broušená a ostatní kamenná industrie z neolitu a eneolitu jižní Moravy se zvláštním zřetelem na lokalitu Těšetice-Kyjovice. Unpublished $\mathrm{PhD}$ dissertation. Brno.

VOKÁČ M., KUČA M., PŘICHYSTAL A. 2005. Využití amfibolického dioritu brněnského masivu v pravěku jižní Moravy. In I. Cheben, I. Kuzma (eds.), Otázky neolitu a eneolitu našich krajín - 2004. Zborník referátov z 23. pracovného stretnutia bádatel'ov pre výskum neolitu a eneolitu Čiech, Moravy a Slovenska. Skalica 21.-24. 9. Nitra: 359367.

WEISS J. 1966. Ultrabazic rocks of the west Moravian crystalline complex. Krystalinikum 4: 171-184.

WOJCIECHOWSKI W. 1983. Neolityczne Górnictwo dolnoslaskich serpentinitów w świetle badań wykopaliskowych na Jánskej Górze. Przegład Archeologiczny 31: 3-46.

ŽEBERA K. 1939. Archeologický výzkum Posázaví. I. zpráva. Neolitické a stř̌edověké vápencové lomy na "Bîém kameni" u Sázavy. Památky archeologické 41: 51-58. 